\title{
PERJUANGAN DAN CABARAN PELAKSANAAN BAHASA KEBANGSAAN DI MALAYSIA, 1957-1966
}

\author{
Sharifah Darmia binti Sharif Adam
}

\begin{abstract}
This article examine the historical development of the national language in Malaysia from 1957-1966. The article discusses the struggles and the challenges faced by the government, non-governmental organizations (NGOs) and specific individuals, and their effort to uphold the national language. In addition it will look at Article 152 (1) of the Federal Constitutions of 1957 that provide for Malay language as the national language of Malaysia. Hence an attempt has been made to consolidate position of the national language in the administration andeducational spheres. One of the steps taken is to foster the mutual relations with Indonesia on aspects of the Malay language. Within that period, another area which is discussed is the importance of the language issues in the election manifesto. To elaborate further, this research also traces the development of the national language in Sabah and Sarawak when both of these states joined Malaysia in 1963.
\end{abstract}

\section{Pengenalan}

Bahasa Melayu telah menjadi lingua franca sejak berabad-abad yang lalu di Kepulauan Melayu. Ia menjadi bahasa perantara dalam urusan pemerintahan dan perdagangan. Tindakan meminggirkan peranan Bahasa Melayu oleh kuasa-kuasa Barat, khususnya pihak Brtish secara langsung menyebabkan perjuangan ke arah memartabatkan Bahasa Melayu semakin ketara pada penghujung abad ke-19. Apabila negara mencapai kemerdekaan pada tahun 1957, Bahasa Melayu telah dimartabatkan sebagai bahasa kebangsaan sebagaimana yang terkandung dalam Perlembagaan Negara. Walau bagaimanapun, termaktubnya Bahasa Melayu sebagai bahasa kebangsaan dalam Perlembagaan Negara bukanlah petanda berakhirnya perjuangan untuk memartabatkan bahasa Melayu. Pengiktirafan Bahasa Melayu sebagai bahasa kebangsaan dan bahasa rasmi negara oleh Perlembagaan Negara telah menimbulkan pelbagai isu, reaksi dan cabaran daripada Bahasa Inggeris serta pihakpihak yang kurang senang terhadap pendaulatan Bahasa Melayu. Oleh itu, artikel yang dibincangkan ini akan meliputi topik seperti kerjasama kebahasaan antara Persekutuan Tanah Melayu dengan Republik 
Indonesia, peranan individu, pertubuhan serta pengaruh badan politik terhadap perkembangan bahasa kebangsaan antara tahun 1957 hingga 1966. Menariknya dalam artikel ini, isu bahasa yang digunakan dalam kempen pilihan raya umum 1959 dan pilihan raya umum 1964 oleh para pemimpin politik turut dikupas. Selain itu, dalam artikel juga akan menyentuh mengenai perkembangan bahasa kebangsaan di Sabah dan Sarawak apabila kedua-dua negeri tersebut menyertai Persekutuan Malaysia pada tahun 1963.

\section{Kerjasama Kebahasaan Antara Malaysia dan Indonesia 1959}

Sebagai sebuah negara yang baru merdeka, pelbagai usaha telah dilakukan untuk mengukuhkan kedudukan bahasa Melayu sebagai bahasa kebangsaan di negara ini. Namun demikian, kerajaan sedar bahawa kedudukan dan usaha ke arah memartabatkan bahasa kebangsaan masih berada di tahap yang rendah. Oleh itu, pada tahun 1959 kerajaan Tanah Melayu telah mengadakan satu kerjasama kebahasaan dengan Republik Indonesia melalui satu perjanjian iaitu Perjanjian Persahabatan. ${ }^{1}$ Perjanjian tersebut merupakan satu lagi peristiwa yang penting dalam sejarah perkembangan bahasa kebangsaan di negara ini. Kerjasama dalam bidang kebahasaan di antara kedua-dua negara berjiran ini amat penting kerana bahasa Indonesia didapati jauh lebih maju berbanding dengan bahasa Melayu di Tanah Melayu. Termeterainya Perjanjian Persahabatan untuk mewujudkan kerjasama antara kedua-dua negara diharap dapat meningkatkan perkembangan bahasa Melayu di Tanah Melayu.

Kemerdekaan Indonesia pada 17 Ogos 1945 yang tercetus lebih awal dari kemerdekaan Malaysia dikatakan merupakan faktor utama yang menyebabkan perkembangan Bahasa Indonesia menjadi lebih pesat berbanding Bahasa Melayu di Malaysia. Melalui kemerdekaan tersebut, kerajaan Republik Indonesia telah menjadikan bahasa Indonesia sebagai bahasa rasmi negara sebagaimana yang termaktub dalam Undang-undang Dasar Sementara Republik Indonesia. ${ }^{2}$ Sejak itu, bahasa Indonesia menjadi bahasa kebangsaan Republik Indonesia dan merupakan satu-satunya bahasa rasmi yang digunakan dalam dewan perwakilan rakyat, dewandewan daerah, perdagangan, suratkhabar, radio serta pendidikan. Perkembangan yang menggalakkan dalam lapangan politik, ekonomi dan sosial yang wujud kesan daripada kemerdekaan Indonesia secara langsung memaksa rakyat Indonesia menggunakan banyak perkataan asing dan bahasa-bahasa daerah yang beratus-ratus jumlahnya. ${ }^{3}$ Ini menjadikan bahasa Indonesia jauh lebih maju dari bahasa Melayu. Sementara itu, di Tanah Melayu bahasa Melayu dilihat agak ketinggalan. Kelewatan negara Malaysia memperoleh kemerdekaan pada 31 Ogos 1957 secara langsung menyebabkan proses untuk mengiktiraf bahasa Melayu sebagai bahasa 
kebangsaan dan bahasa rasmi negara menjadi sukar untuk direalisasikan. Masalah bahasa Melayu yang mengalami hambatan akibat tentangan daripada bahasa Inggeris, bahasa Cina dan bahasa Tamil juga telah menyebabkan bahasa Melayu sebagai bahasa kebangsaan dan bahasa rasmi negara sukar dimajukan. ${ }^{4}$

Kewujudan beratus-ratus perkataan dan cara perbahasaan baru ke dalam bahasa Indonesia seperti bahasa Jawa, Sunda, Madura, Bali, Makasar, Bugis, Ambon, Minangkabau, Batak Mendailing dan sebagainya secara langsung telah menyebabkan bahasa Melayu di Indonesia telah mengalami perubahan yang besar pada awal abad ke-20 berbanding perkembangan bahasa Melayu di Malaysia. Selain itu, terdapat juga beratus-ratus perkataan daripada bahasa Belanda yang diserap ke dalam bahasa Indonesia. ${ }^{5}$ Kesemua ini menjadikan bahasa Indonesia lebih kaya dan maju dari segi istilah. Sementara itu, di Malaysia pula perkembangan bahasa Melayu agak ketinggalan dan terbatas kerana hanya memperoleh sedikit perkataan pinjaman dan sumbangan daripada bahasa-bahasa asing seperti bahasa Arab, Inggeris, Tamil dan Cina. Oleh itu, tidak hairanlah apabila dilihat bahawa bahasa Indonesia lebih maju berbanding bahasa Melayu di Malaysia.

Wujudnya kerjasama kebahasaan antara Malaysia dan Indonesia adalah bertujuan untuk meningkatkan kesefahaman politik dan pencapaian matlamat pembangunan sosio ekonomi di antara kedua-dua buah negara tersebut. Dilihat dari segi komunikasi, penyatuan bahasa Melayu ini secara langsung dapat mengoptimumkan peluang interaksi di antara rakyat Malaysia dengan rakyat Indonesia. ${ }^{6}$ Malah, penyatuan juga dapat memberikan ganjaran ekonomi yang lebih besar kepada penulis, penerbit, pencetak dan pengedar buku yang menggunakan bahasa Melayu. ${ }^{7}$ Kesemua perkara ini akan meningkatkan mutu bahasa Melayu dan memudahkan penyebaran ilmu pengetahuan dalam bahasa tersebut.

Sebagai usaha untuk merealisasikan cita-cita kerjasama kebahasaan ini, kerajaan Malaysia telah mewujudkan jalinan perhubungan dan persatuan bahasa dengan pemerintah Indonesia. Kerjasama kebahasaan ini ditandatangani oleh Tun Abdul Razak yang pada ketika itu memegang jawatan Timbalan Perdana Menteri Persekutuan Tanah Melayu dengan Ir. H. Djuanda yang memegang jawatan Perdana Menteri Indonesia. ${ }^{8}$ Melalui jalinan kerjasama ini, termeterailah satu perjanjian persahabatan antara Persekutuan Tanah Melayu dengan Republik Indonesia pada 17 April 1959. Merujuk kepada Perkara 6 perjanjian, telah menyebut berhubung dengan penyamaan bahasa di kedua-dua negara. ${ }^{9}$ 
Berikut diturunkan isi kandungan perjanjian persahabatan antara Persekutuan Tanah Melayu dengan Republik Indonesia pada tahun 1959:

\section{Perkara 1}

Kedua pihak tertinggi yang mengikat perjanjian ini akan saling menghormati kemerdekaan dan kedaulatan satu sama lain dan akan berusaha memelihara ikatan yang turun temurun, ikatan kebudayaan dan sejarah yang merapatkan mereka.

\section{Perkara 2}

Kedua pihak tertinggi yang mengikat perjanjian ini bersetuju memelihara dan melanjutkan perhubungan diplomatik dan konsul di antara kedua pihak mengikut lunas-lunas dan kebiasaan antara bangsa-bangsa, serta bersetuju bahawa wakil-wakil diplomatik dan konsul di antara satu pihak dengan lain itu akan menikmati, di atas dasar timbal balik segala hak-hak, keistimewaan-keistimewaan, kechualian-kechualian dan kebebasan yang ditentukan bagi pegawai-pegawai setimbal dengan taraf dan pangkat menurut lunas-lunas yang amnya telah diterima bagi undang-undang dan kebiasaan antarabangsa.

\section{Perkara 3}

Kedua pihak tertinggi yang mengikat perjanjian, dengan syarat diberi pertimbangan kepada perkara-perkara keselamatan ketenteraman umum, kesihatan umum dan kawalan imigresen bagi kedua buah negara itu, menyedari bahawa warganegara masing-masing hendaklah dikenakan sekatan yang seringan-ringannya tatkala

(a) melakukan perjalanan di antara dan di dalam dua buah negara dan (b) berkediaman

dalam dua buah negara itu, bersetuju mengkaji akan apa-apa sekatan yang dikenakan dan kesulitan yang dialami sekarang oleh warganegara masing-masing yang melakukan perjalanan dan yang berkediaman itu dengan maksud hendak mencapai persetujuan mengurangkan kesulitan yang demikian itu atau memudahkan atau menghapuskan sekatansekatan yang demikian itu di atas dasar timbal balik.

\section{Perkara 4}

Kedua pihak tertinggi yang mengikat perjanjian bersetuju bahawa jika berbangkit apa-apa perselisihan di atas perkara-perkara yang tepat dan tertentu mengenai kedua pihak itu, maka hendaklah keduanya berikhtiar menyelesaikan perselisihan yang demikian itu menerusi saluran diplomatik dengan semangat persahabatan dan muhibah yang sejati. Jika tiada diperoleh penyelesaian menerusi saluran yang tersebut dalam masa berpatutan, maka hendaklah kedua pihak itu berikhtiar menyelesaikannya dengan cara dan jalan lain menurut Piagam Bangsa-Bangsa Bersatu dan lunas-lunas yang diisytiharkan dalam Persidangan Asia-Afrika di Bandung 1955. 


\section{Perkara 5}

Kedua pihak tertinggi yang mengikat perjanjian untuk hendak mengadakan kerjasama yang lebih rapat, bersetuju mengkaji soal-soal yang berkait dengan perhubungan konsul, perdagangan, perhubungan, penyerahan orang-orang yang melakukan kesalahan-kesalahan yang melarikan diri serta lain-lain perkara bagi kepentingan bersama, dengan maksud, pada bila-bila waktu dan masa yang sebolehnya, mencapai persetujuan di atas dasar timbal balik.

\section{Perkara 6}

Kedua pihak tertinggi yang mengikat perjanjian sedar akan hal bahawa bahasa Melayu dan Indonesia ialah berasal sama, akan berusaha dengan cara kerjasama, bantu membantu dan perundingan untuk mencapai persamaan seberapa luas yang boleh dalam perkembangan dan penggunaannya.

\section{Perkara 7}

Kedua pihak tertinggi yang mengikat perjanjian dengan hasrat hendak mencapai sepenuh-penuh kerjasama dalam lapangan-lapangan kebudayaan, kesarjanaan, sains dan pelajaran, dengan syarat-syarat diberi pertimbangan kepada perkara-perkara keselamatan dan ketenteraman umum dalam negara masing-masing bersetuju:

(a) Memajukan pertukaran ahli-ahli pelajaran, ahli-ahli sains, guruguru, penuntut-penuntut, kumpulan-kumpulan penyelidikan, ahliahli seni serta wakil-wakil dari pertubuhan-pertubuhan masyarakat dan kebudayaan.

(b) Memajukan pertukaran pendapat-pendapat dan hasil penyelidikan sains dan umum.

(c) Memajukan melalui saluran-saluran rasmi pertukaran penerbitanpenerbitan pelajaran dan kebudayaan, filem, akhbar-akhbar, ulasanulasan dan siaran-siaran radio supaya menambahkan pengetahuan dan saling pengertian.

(d) Memajukan pertukaran benda-benda yang bernilai purbakala, sejarah dan kebudayaan.

(e) Berbantu-bantu di antara satu dengan lain untuk memajukan latihan dalam lapangan-lapangan pelajaran, sains, teknologi dan perusahaan.

(f) Menggalak dan memudahkan kerja-kerja untuk mengadakan sandiwara-sandiwara dan pertunjukan-pertunjukkan kesenian, sains dan kesusasteraan.

(g) Menggalakkan penuntut-penuntut dari negara satu pihak menuntut di dalam universiti-universiti dan badan-badan pelajaran di negara pihak yang lain.

(h) Menggalak dan memajukan pergerakan dalam lapangan sukan di antara kedua buah negara dan 
(i) Melindungi harta benda kebudayaan dan purbakala di antara kedua buah negara selagi perkara ini tidak terkandung dalam persetujuan-persetujuan umum yang bersifat antarabangsa.

Perkara 8

Perjanjian ini hendaklah berjalan kuatkuasanya pada tarikh pertukaran surat-surat pengesahan yang akan dilakukan dengan seberapa segeranya di Jakarta.

\section{Perkara 9}

Tiap-tiap pihak tertinggi yang mengikat perjanjian adalah berhak membatalkan perjanjian ini dengan suatu pemberitahu kepada pihak yang lainnya dan pembatalan yang demikian itu akan berlaku setelah habis tempoh enam bulan dari tarikh pemberitahu yang tersebut.

Perkara 10

Perjanjian ini adalah diperbuat dalam bahasa Melayu, Indonesia dan Inggeris yang mempunyai nilai yang sama. Sebarang tafsiran yang bertelingkah mengenai ketiga-tiga kandungan perjanjian ini hendaklah diselesaikan melalui perundingan. ${ }^{10}$

Berdasarkan Perkara 6 Perjanjian Persahabatan ini, kerajaan akan dapat menyediakan bahasa Melayu untuk pertumbuhan yang lebih maju bagi memenuhi kehendak-kehendak zaman baru. Kesan kerjasama tersebut, penuntut-penuntut dari Tanah Melayu telah dihantar ke Indonesia melalui tajaan biasiswa pemerintah Indonesia ${ }^{11}$ untuk mengikuti pengajian di Universiti Indonesia, Jakarta dalam bidang bahasa dan kesusasteraan Indonesia. ${ }^{12}$ Tajaan biasiswa dari pemerintah Indonesia ini amat penting untuk perkembangan bahasa Melayu dan juga pengurangan jarak antara bahasa Melayu dan bahasa Indonesia. ${ }^{13}$ Perkembangan bahasa Indonesia dan kesusateraan Indonesia yang lebih maju ke hadapan berbanding bahasa Melayu secara langsung menjadikan tajaan daripada pemerintah Indonesia amat penting. Oleh yang demikian, Indonesia menjadi rujukan utama bagi Tanah Melayu dalam hal-hal yang menyangkut bahasa dan kesusasteraan Melayu. ${ }^{14}$

Di samping itu, dalam bulan Disember 1959 rombongan bahasa dari Persekutuan Tanah Melayu telah mengunjungi Indonesia untuk membincangkan ejaan bersama yang dikenali sebagai ejaan Melindo. ${ }^{15}$ Rombongan ini diketuai oleh Tuan Syed Nasir Bin Ismail (Pengarah Dewan Bahasa dan Pustaka) ${ }^{16}$ yang mengadakan pertemuan dengan 
rombongan Indonesia yang diketuai oleh Profesor Dr. Slametmuljana. ${ }^{17}$ Mereka bermesyuarat pada 4 hingga 7 Disember 1959 bertempat di Gedung Proklamasi, Jakarta. ${ }^{18}$ Walau bagaimanapun, sistem ejaan ini tidak pernah dilaksanakan kerana didapati tidak praktikal. ${ }^{19}$

Ekoran Perjanjian Persahabatan itu juga, pada 1 Ogos 1959, pemerintah Indonesia telah membentuk sebuah Panatia Pelaksanaan Kerjasama Bahasa Melayu-Indonesia. ${ }^{20}$ Manakala, kerajaan Persekutuan Tanah Melayu pula telah menubuhkan Jawatankuasa Bersama Tentang Soal Bahasa Persekutuan Tanah Melayu-Indonesia pada 21 Oktober 1959 dan diketuai oleh Pendeta Za'ba. ${ }^{21}$ Tindakan ini adalah bertujuan untuk menyelaraskan bahasa di antara kedua-dua negara. Kesan daripada tindakan penyelarasan bahasa antara kedua-dua negara telah menjadikan bahasa Melayu mampu mengukuhkan kedudukannya sebagai bahasa kebangsaan dan bahasa rasmi serta menjadi alat untuk memudahkan komunikasi dengan negara jiran. Namun kerja-kerja menyelaraskan soal bahasa ini terbantut kerana berlaku konfrontasi ${ }^{22}$ antara Persekutuan Tanah Melayu dengan Indonesia yang menentang pembentukan Malaysia pada 1963. Ia kemudiannya disambung semula pada 20 september 1966, apabila satu rombongan yang diketuai Syed Nasir Ismail yang memegang jawatan pengarah Dewan Bahasa dan Pustaka (DBP) ketika itu berkunjung ke Indonesia untuk mempercepatkan pelaksanaan persamaan sistem ejaan dan bahasa Indonesia-Malaysia. ${ }^{23}$

\section{Peranan Individu Dan Pertubuhan-Pertubuhan Dalam Perkembangan Bahasa Kebangsaan}

Peranan penting individu dan pertubuhan-pertubuhan ke arah usaha melaksanakan pengunaan bahasa kebangsaan di negara ini sememangnya tidak dapat dinafikan. Individu-individu tersebut terdiri daripada golongan intelek, pegawai kerajaan, peguam, pensyarah universiti, guru dan penulis. Sementara itu, pertubuhan yang terlibat pula terdiri daripada parti politik, pertubuhan pelajar seperti Persatuanpersatuan Pelajar Maktab Perguruan Bahasa, kesatuan guru, persatuan penulis, akhbar dan majalah serta sebuah pertubuhan khas yang ditubuhkan untuk mendesak kerajaan supaya melaksanakan dasar bahasa. Kemunculan individu dan pertubuhan-pertubuhan yang bergiat aktif dalam kegiatan berhubung bahasa kebangsaan boleh dikatakan kesan daripada sikap golongan tertentu dalam kalangan orang Melayu dan orang bukan Melayu yang berterusan mempertahankan kedudukan bahasa Inggeris, bahasa Cina mahupun bahasa Tamil. Sedangkan golongan ini sendiri menyedari hakikat bahawa pengiktirafan bahasa Melayu sebagai bahasa kebangsaan bagi negara ini merupakan sebahagian daripada perjanjian kemerdekaan yang telah dipersetujui 
bersama. ${ }^{24}$ Perkembangan yang tidak sihat ini telah mewujudkan kegusaran di hati para pejuang bahasa Melayu yang secara jelas menunjukkan perasaan kurang senang mereka dengan situasi itu.

Antara usaha individu dalam mengembang dan memperluaskan penggunaan bahasa kebangsaan misalnya dapat dilihat melalui surat yang ditulis oleh Ustaz Zulkifli Muhammad, Pengetua Kolej Islam Malaya (KIM) pada tahun 1957. Surat tersebut dihantar kepada Za'ba yang memegang jawatan Ketua Jabatan Pengajian Melayu, Universiti Malaya, Singapura bertujuan untuk memohon silibus subjek bahasa Melayu yang diajar di jabatan tersebut. ${ }^{25}$ Isi kandungan surat tersebut berbunyi:

Dengan hormatnya dimaklumkan bahawa dalam susunan pelajaran kolej ini adalah menjadikan bahasa Melayu sebagai satu matapelajaran yang penting. Maka bagi memuktamadkan butir-butir pengajian Melayu, disini besarlah harapan saya jika tuan bermurah hati mengirimkan susunan pelajaran bahasa Melayu yang dipakai di bidang tuan satu-satunya. Tujuan mengajarkan bahasa Melayu, bukan semata-mata bagi mendalamkan kajian itu pada penuntut-penuntut baik juga untuk memberi sumbangan ilmiah bagi perkembangan bahasa itu sendiri. ${ }^{26}$

Surat ini menunjukkan bahawa terdapatnya usaha daripada Pengetua Kolej Islam Malaya (KIM) untuk memperluaskan penggunaan bahasa kebangsaan di kolej tersebut. Malahan yang lebih menarik di kolej inilah tertubuhnya sebuah persatuan yang dinamakan sebagai Persatuan Penuntut-penuntut Kolej Islam Malaya (PPKIM) pada Julai 1957. PPKIM merupakan sebuah persatuan yang terlibat secara langsung dalam kegiatan memperjuangkan kedudukan bahasa kebangsaan. Perjuangan persatuan ini untuk mempertahankan bahasa kebangsaan mencapai kemuncaknya pada tahun 1967 apabila pelajar-pelajar KIM di Petaling Jaya telah mengadakan demonstrasi seterusnya menyebabkan KIM terpaksa ditutup. ${ }^{27}$ Sementara itu, antara pertubuhan orang Melayu yang aktif dalam menjalankan kegiatan yang bersabit dengan bahasa dan merupakan pertubuhan yang menyatakan objektifnya sebagai pertubuhan yang secara tegas memperjuangkan dasar bahasa negara ialah Persatuan Bahasa Melayu Universiti Malaya (PBMUM) ${ }^{28}$ Persatuan Penulis Nasional (PENA) dan Pertubuhan khas yang dikenali sebagai Barisan Bertindak Bahasa Kebangsaan (BBBK).

PBMUM dalam usaha mengembangkan bahasa kebangsaan telah memberi reaksi terhadap ucapan Tunku Abdul Rahman (Perdana Menteri Malaysia) mengenai bahasa pada 21 Oktober 1966. Dalam ucapan tersebut, Tunku telah menyatakan bahawa kerajaan bersedia menggunakan secara liberal bahasa lain sekiranya orang ramai mempunyai sikap yang betul dan pendekatan yang wajar. Selain itu, 
beliau juga menyatakan bahawa bahasa Inggeris penting dan sekiranya bahasa Inggeris digantikan seluruhnya dengan bahasa kebangsaan, pentadbiran akan menjadi kucar-kacir.

Kenyataan Tunku ini menyebabkan PBMUM mengadakan persidangan tergempar pada 24 Oktober $1966 .{ }^{29}$ Hasil persidangan tersebut, satu penulisan yang mengkritik kerajaan bertajuk "Dasar Liberal Tungku dan Super-Liberal Khir (nama Menteri Pelajaran ketika itu)" telah diterbitkan melalui Suara PBMUM pada bulan November 1966. Tulisan ini antara lain menggesa supaya kerajaan memberikan peluang kepada bahasa kebangsaan untuk memainkan peranan sebagai alat perhubungan dan alat perpaduan nasional serta meminta supaya persaingan daripada bahasa lain dilenyapkan. ${ }^{30}$ Jelaslah PBMUM cuba menggunakan hasil penerbitannya sebagai alternatif untuk mengangkat martabat bahasa kebangsaan.

Seterusnya, PENA pula merupakan sebuah badan penulis yang ditubuhkan pada 12 Februari 1961 dengan tujuan untuk mengembangkan lapangan bahasa, kesusasteraan dan ilmu pengetahuan bersesuaian dengan kepentingan-kepentingan nasional dengan tidak terikat kepada dasar politik kepartian atau terkeluar daripada bidang undang-undang negara. Ini jelas menunjukan peranan aktif yang dimainkan oleh PENA dalam hal bersabit bahasa dan kesusasteraan. Selain itu, PENA juga terlibat secara aktif dalam memperjuangkan pelaksanaan bahasa Melayu sebagai bahasa pengantar utama dalam sistem pelajaran kebangsaan.

Sementara itu, BBBK telah ditubuhkan pada 7 Julai 1964 khusus untuk mendaulatkan bahasa kebangsaan sebagai bahasa rasmi yang tunggal menjelang tahun 1967 . Dua tujuan lain penubuhannya ialah untuk melaksanakan kehendak perlembagaan negara sebagaimana yang termaktub dalam perkara 152 dan menimbulkan semangat cinta serta semangat perjuangan terhadap bahasa kebangsaan. Antara usaha BBBK ialah mengadakan siaran penerangan, ceramah, rapat umum dan memberikan sokongan kuat kepada pejuang bahasa. BBBK yang dipimpin oleh Syed Nasir bin Ismail (Pengarah Dewan Bahasa dan Pustaka) mendapat sokongan daripada ahli-ahli Umno, ahli Parlimen Persekutuan, guru-guru sekolah Melayu, wartawan dan penuntut-penuntut universiti. ${ }^{31}$ Oleh itu, jelas menunjukkan bahawa usaha dan tanggungjawab untuk mengembang serta memperluaskan penggunaan bahasa kebangsaan tidak hanya dipikul oleh kerajaan tetapi juga turut dibantu oleh individu dan pertubuhan. Peranan dan usaha yang dilaksanakan secara langsung membantu untuk mempercepatkan proses perkembangan dan pelaksanaan pengunaan bahasa kebangsaan di negara ini. Selain itu, isu ini juga telah memperlihatkan betapa pentingnya persoalan bahasa dibangkitkan kerana 
ianya mampu melahirkan kerjasama dan perpaduan dalam membangkitkan kesedaran untuk mempertahankan bahasa kebangsaan.

\section{Isu Bahasa Kebangsaan Dalam Pilihan raya Umum}

Dalam tempoh antara 1957 sehingga 1966 terdapat dua pilihan raya yang berlangsung di Tanah Melayu iaitu pilihan raya pada tahun $1959^{32}$ dan pilihan raya pada tahun $1964 .{ }^{33}$ Isu bahasa kebangsaan dalam pilihan raya umum 1959 dan 1964 seringkali dieksploitasi oleh pemimpinpemimpin politik sebagai manifesto kempen-kempen. Semua ini adalah bertujuan untuk memancing undi daripada rakyat. Dalam masa yang sama, kerajaan akan sedaya upaya mempertahankan diri sementara pembangkang pula akan berusaha menonjolkan keburukan untuk mengalahkan lawannya. ${ }^{34}$ Walaupun isu bahasa tersebut telah berjaya meraih undi daripada rakyat, namun dilihat dari sudut yang berlainan, ianya telah menyebabkan tercetusnya pergeseran yang hebat antara kaum. Ini disebabkan oleh sikap sesetengah tokoh politik yang mengambil kesempatan dengan menjadikan isu bahasa sebagai jambatan untuk menegakkan kekuasaan politik mereka.

Selain itu, desakan dan tuntutan orang bukan Melayu untuk menjadikan bahasa Cina dan bahasa Tamil sebagai bahasa rasmi didapati begitu kuat. ${ }^{35}$ Tuntutan tersebut secara terbuka dan berani mencabar perlembagaan yang telah menetapkan bahawa bahasa Melayu merupakan bahasa kebangsaan dan bahasa rasmi bagi negara ini. Malahan akibat perhatian yang diberikan oleh akhbar-akhbar terhadap isu bahasa menyebabkan Tun Abdul Razak meminta kepada wartawan akhbar supaya tidak mengapi-apikan masalah yang melibatkan bahasa. ${ }^{36}$ Tindakan yang dilakukan adalah untuk mengelakkan ketegangan yang lebih serius antara kaum Melayu dan kaum bukan Melayu.

Menjelang pilihan raya 1959, isu bahasa telah menjadi tema utama bagi parti-parti politik yang bertanding untuk menarik dan mempengaruhi pengundi. ${ }^{37}$ Sebagai sebuah negara yang baru sahaja merdeka, sudah pasti kedudukan bahasa merupakan persoalan pokok yang sentiasa mendapat perhatian rakyat. Justeru itu, sudah pasti tokoh-tokoh politik menjadikan persoalan ini sebagai sasaran mereka dalam peperangan pilihan raya 1959.

Kerajaan Perikatan dalam manifesto kempen-kempennya ketika pilihan raya tahun 1959 berhubung bahasa kebangsaan menyatakan bahawa sekiranya mereka dipilih memegang kuasa pemerintahan di Persekutuan Tanah Melayu, dasar pelajaran yang sedia ada akan dikaji semula dengan berpandukan kepada pengalaman yang telah diperoleh. Sejak dasar pelajaran dijalankan, ianya secara langsung mengingatkan tujuan yang telah ditetapkan untuk menjadikan bahasa Melayu sebagai 
bahasa rasmi, menggalak dan mengawal perkembangan bahasa-bahasa dan kebudayaan-kebudayaan bangsa lain. ${ }^{38}$ Bagi mempelajari bahasa kebangsaan di sekolah-sekolah, Perikatan telah memberi jaminan akan meneruskan usaha untuk mengadakan kemudahan yang lebih baik. Di samping itu, Perikatan akan terus memajukan rancangan memperluaskan kerja-kerja DBP menurut tujuan dan cita-cita yang telah ditentukan bagi menjadikan bahasa Melayu sebagai bahasa kebangsaan dan bahasa rasmi dalam tempoh sepuluh tahun daripada tarikh kemerdekaan sebagaimana yang telah ditetapkan. ${ }^{39}$ Melalui manifesto ini jelaslah bahawa Perikatan menggunakan isu bahasa kebangsaan sebagai usaha untuk menarik undian rakyat khususnya orang Melayu.

Sementara itu, reaksi orang bukan Melayu dan parti-parti pembangkang mengenai isu bahasa juga dapat dilihat dalam pilihan raya umum 1959. Walaupun perlembagaan Persekutuan Tanah Melayu 1957 dengan jelas telah menetapkan bahawa bahasa Melayu sebagai bahasa kebangsaan dan bahasa rasmi bagi negara ini, namun ahli-ahli politik bukan Melayu khususnya orang Cina masih lagi lantang dan terbuka mempersoalkan serta menentang kedudukan bahasa Melayu. Pada April 1959, kaum Cina telah mendesak supaya MCA memainkan peranan untuk menyalurkan perasaan tidak puas hati mereka terhadap Laporan Penyata Razak. Ini disebabkan orang Cina menganggap Laporan Penyata Razak tersebut tidak adil kerana hanya mewajibkan bahasa Melayu di sekolah Melayu dan bahasa Inggeris di semua jenis sekolah. Oleh itu, mereka menuntut supaya penggunaan bahasa Cina (Kou Yu) dilaksanakan di sekolah. Tuntutan ini dikemukakan oleh dua pertubuhan iaitu, United Chinese School Teacher Association dan All Malay Chinese School Manegement Association. ${ }^{40}$

Di samping itu, parti politik pembangkang seperti Parti Barisan Sosialis dan Parti Buruh tetap berdegil mengemukakan tuntutan mereka untuk menjadikan bahasa Cina dan bahasa Tamil sebagai bahasa rasmi. Alasan yang diberikan oleh mereka adalah kenyataan bahawa negara ini terdiri daripada penduduk yang mempunyai pelbagai bahasa di samping jumlah penduduk tempatan dan orang luar yang hampir sama banyak. Kesemua ini dijadikan manifesto yang wajib kepada setiap parti yang ingin menarik pengundi bagi kemenangan dalam pilihan raya 1959 itu. ${ }^{41} \mathrm{Hal}$ ini secara langsung telah menyebabkan ketegangan ras berlaku. Selain itu, reaksi orang bukan Melayu melalui parti politik dan pertubuhan yang mewakili mereka juga dapat dilihat melalui tuntutan supaya bahasa Cina dan bahasa Tamil digunapakai sebagai bahasa pengantar dan bahasa dalam peperiksaan di sekolah Cina dan Tamil. Sebagai contohnya, Parti Buruh begitu lantang membuat tuntutan agar bahasa Cina dan bahasa Tamil dijadikan bahasa pengantar di sekolah menengah. Sementara itu, 
D.R. Seenivasagam yang merupakan Setiausaha Agung Parti Progresif Rakyat telah membangkitkan persoalan mengenai bahasa kaum lain seperti kaum Cina yang tidak diberikan taraf rasmi sedangkan terdapat 2 juta penduduk Cina di Tanah Melayu. ${ }^{42}$ Parti ini juga menuntut supaya bahasa Cina dan bahasa Tamil dijadikan bahasa rasmi di samping bahasa kebangsaan serta bahasa pengantar di sekolah ibunda masing-masing. ${ }^{43}$ Kesemua tuntutan ini benar-benar mewujudkan suasana tegang dan dingin antara kaum Melayu dan kaum bukan Melayu seterusnya menghalang usaha pengembangan bahasa kebangsaan.

Sementara itu, orang Melayu berpegang teguh dengan pendirian bahawa tidak akan wujud bahasa asing yang menjadi bahasa kebangsaan mahupun bahasa rasmi di negara ini selain bahasa Melayu. Ini cukup menggambarkan bahawa isu bahasa merupakan satu persoalan yang sangat penting bagi orang Melayu. Sebagai contoh, kesan daripada kegagalan UMNO memenuhi tuntutan Kesatuan Persekutuan Guru-guru Melayu Semenanjung (KPGMS) yang mahukan supaya kerajaan melaksanakan bahasa Melayu sebagai bahasa pengantar di sekolah menengah telah mewujudkan ketegangan antara KGPMS dan UMNO. Tuntutan KPGMS ini juga didorong oleh kebimbangan bahawa kerajaan akan tunduk kepada tuntutan orang Cina dan orang India yang menuntut supaya bahasa mereka diangkat menjadi bahasa rasmi sama seperti bahasa Melayu. Tindakan KPGMS turut mendapat sokongan daripada UMNO bahagian di Pulau Pinang yang kemudiannya mengeluarkan arahan kepada semua ahlinya dalam Majlis Mesyuarat Negeri dan Persekutuan supaya keluar beramai-ramai dari UMNO sekiranya bahasa Melayu tidak dijadikan bahasa pengantar menjelang 1 Februari $1958 .{ }^{44}$ Di samping itu, KPGMS turut disokong oleh Persatuan Islam Se-Tanah Melayu (PAS). Sokongan PAS jelas dilihat melalui laporan yang terdapat dalam akhbar Straits Times bertarikh 10 Ogos 1959 yang menyatakan bahawa antara kandungan yang terdapat dalam manifesto PAS semasa pilihan raya tahun 1959 ialah bahasa Melayu harus segera dijadikan bahasa kebangsaan dan satu-satunya bahasa rasmi di negara ini. Selain itu, dasar pelajaran juga perlu diubah supaya dapat menghasilkan satu sistem yang lebih berorientasikan Melayu. ${ }^{45}$ Jelas bahawa tindakan PAS ini dilihat sebagai cuba memancing undi melalui isu bahasa ataupun dengan kata lain 'cuba menangguk di air keruh'.

Buktinya, PAS berjaya mengambil kesempatan atas ketegangan yang wujud antara KPGMS dan UMNO apabila tuntutan KPGMS gagal dipenuhi oleh kerajaan, hampir 10,000 orang guru Melayu meninggalkan UMNO. Akibatnya, kerajaan Perikatan (UMNO) telah kehilangan kuasanya di negeri Kelantan dan Terengganu manakala Kedah pula hampir berjaya dikuasai oleh parti pembangkang. ${ }^{46}$ Oleh yang demikian 
jelaslah para pemimpin PAS secara terang-terangan menentang Perikatan dengan melemparkan tuduhan bahawa Perikatan telah menjual kedaulatan bahasa Melayu. Oleh itu, untuk menarik sokongan pengundi, PAS dalam kempennya telah mendesak supaya bahasa Melayu dijadikan bahasa rasmi dan tunggal di negara ini. ${ }^{47}$

Pada tahun yang sama juga Malayan Indian Congress (MIC) telah dibidas secara terang-terangan apabila mengemukakan tuntutan untuk menjadikan bahasa Inggeris sebagai bahasa kedua. ${ }^{48}$ Tuntutan MIC itu dianggap akan menjejaskan usaha untuk menjadikan bahasa Melayu sebagai bahasa kebangsaan dan bahasa rasmi yang tunggal kerana hanya dengan menggunakan satu bahasa sahaja akan menyatupadukan semua kaum di negara ini. Ekoran daripada itu, MIC dituduh mengambil tindakan yang boleh dianggap sebagai mengoyakkan Perlembagaan Persekutuan kerana keputusan mereka supaya kerajaan persekutuan menjadikan bahasa Inggeris sebagai bahasa kedua seolah-olah menunjukkan mereka tidak taat setia pada negara dan dianggap memandang rendah dengan kemampuan bahasa kebangsaan.

Insiden ini juga telah menyebabkan Syed Nasir Ismail, Pengarah DBP ketika itu bertindak menghantar buku-buku dan risalah-risalah yang diterbitkan oleh DBP mengenai sejarah dan perkembangan bahasa Melayu kepada Presiden MIC. Tujuannya adalah untuk menyedarkan Presiden MIC akan kekuatan pengaruh bahasa Melayu. Malahan keputusan MIC untuk menjadikan bahasa Inggeris sebagai bahasa kedua dianggap Syed Nasir Ismail sebagai satu tindakan yang nyata bertentangan dan tidak bersesuaian dengan dasar kerajaan persekutuan, parti Perikatan dan Perlembagaan Persekutuan Tanah Melayu. ${ }^{49}$

Seterusnya, dalam pilihan raya umum 1964 isu utama yang dibangkitkan dalam kempen tokoh-tokoh politik ialah konfrontasi dengan Indonesia berhubung pembentukan Malaysia yang menyaksikan penyertaan Sabah, Sarawak dan Singapura ke dalam Persekutuan Malaysia pada tahun $1963 .{ }^{50}$ Ketika itu, parti pembangkang seperti Barisan Sosialis dan PAS telah menentang penubuhan Malaysia sehingga mereka dituduh pro-Indonesia. Hal ini telah menyebabkan beberapa orang ahlinya telah ditahan. ${ }^{51}$

Selain itu, Perikatan yang bimbang akan mengalami kekalahan di Kelantan dan Pulau Pinang telah memberi amaran kepada para pengundi bahawa mereka akan menghadapi akibat buruk sekiranya parti pembangkang menguasai negeri. Ini disebabkan kerajaan negeri tidak akan bekerjasama dengan kerajaan persekutuan. Oleh itu, di Kelantan misalnya, kerajaan Perikatan telah menyebarkan 100,000 risalah yang menuduh PAS menggadaikan 375,000 ekar tanah kepada sebuah firma Cina dengan harga yang paling murah. ${ }^{52}$ 
Di samping itu, kerajaan Perikatan juga mendakwa kerajaan negeri tidak mentadbir kewangan dengan baik dan menghalang rancangan pembangunan kerajaan persekutuan untuk negeri. Sebagai contoh, kemajuan yang telah dicapai oleh Terengganu setelah negeri itu dikuasai semula oleh Perikatan. Sementara itu, di Pulau Pinang yang mempunyai ramai penduduk menjalankan perniagaan, Perikatan berjanji untuk mengekalkan status pelabuhan bebas sekiranya ia dipilih semula. ${ }^{53}$ Hasilnya, Perikatan berjaya menguasai Pulau Pinang tetapi Kelantan masih kekal dalam penguasaan PAS.

Dalam pilihan raya 1964 juga didapati kebanyakan parti pembangkang cuba membangkitkan isu perkauman. Antaranya, isu bahasa masih lagi dipolitikkan apabila People's Action Party (PAP) di bawah pimpinan Lee Kuan Yew mengemukakan konsep Malaysian Malaysia ${ }^{54}$ Konsep Malaysian Malaysia tersebut dilihat sebagai mencabar kerajaan. Ini berikutan daripada rasa tidak puas hati mereka kepada Penyata Razak yang dianggap sebagai suatu tindakan yang cuba menjadikan Persekutuan sebagai negara orang Melayu sahaja. Kaum bukan Melayu juga berpendapat bahawa bahasa Melayu adalah bahasa orang Melayu dan sebagai alat perpaduan bangsa Melayu. Justeru itu, bahasa Cina dan bahasa Tamil tentulah juga bahasa perpaduan bagi orang Cina dan orang Tamil. Oleh yang demikian, tentulah sukar menyatu-padukan semua kaum yang mempunyai bahasa ibunda masingmasing. ${ }^{55} \mathrm{Hal}$ ini jelas menunjukkan pihak pembangkang masih menggunakan isu bahasa sebagai senjata yang bertujuan untuk meraih undian rakyat dan mencabar kerajaan.

Justeru itu, kepopularan isu bahasa yang menjadi kelaziman dalam manifesto parti-parti politik ketika pilihan raya tahun 1959 dan 1964 bukan sahaja memberi kesan terhadap perkembangan bahasa kebangsaan tetapi juga telah meluaskan lagi keretakan hubungan antara kaum di Tanah Melayu. Perkara inilah yang seterusnya mengakibatkan tercatatnya satu titik hitam dalam sejarah negara ini.

\section{Perkembangan Bahasa Kebangsaan di Sabah dan Sarawak}

Pembentukan Malaysia pada 16 September 1963,56 bukan hanya bermakna pembebasan beberapa buah negeri yang dijajah tetapi adalah untuk membentuk satu bangsa yang bersatu padu. Dengan kata lain, pembentukan Malaysia bukan sahaja membantu negeri Sabah, Sarawak, Brunei dan Singapura mencapai kemerdekaan yang lebih cepat tetapi juga membantu negeri-negeri tersebut untuk sama-sama menjadi satu bangsa yang bersatu dan kuat. Oleh yang demikian, satu-satunya jalan yang paling sesuai untuk membentuk perpaduan semangat kebangsaan bagi negeri-negeri di dalam Persekutuan Malaysia ialah melalui alat 
bahasa kebangsaan.

Berhubung dengan perkembangan bahasa kebangsaan di Sabah dan Sarawak, peruntukan-peruntukan khas berhubung kedua-dua negeri ini terkandung dalam Perkara 161 Perlembagaan negara. ${ }^{57}$ Ini disebabkan apabila Sabah dan Sarawak menyertai Malaysia dalam tahun 1963, jangka masa sepuluh tahun diberikan untuk menggunakan bahasa Inggeris dengan bahasa Melayu sebagai bahasa rasmi. ${ }^{58}$ Justeru itu, apa pun yang terkandung dalam Perkara 152 berhubung soal bahasa kebangsaan, bahasa bumiputera yang digunakan di Sabah dan Sarawak boleh digunakan dalam mahkamah-mahkamah bumiputera atau untuk apa-apa kanun undang-undang dan adat istiadat bumiputera. ${ }^{59}$ Selain itu, wakil-wakil dari Sabah dan Sarawak boleh menggunakan bahasa Inggeris dalam Parlimen Persekutuan, mahkamah dikedua-dua buah negeri dan dalam rayuan mereka sehingga tahun 1973. Di samping itu, bahasa Inggeris juga boleh digunakan dalam kedua-dua buah dewan negeri atau untuk tujuan rasmi yang lain. ${ }^{60}$

Menurut perenggan 28 dalam Perjanjian London seperti yang terkandung dalam Peruntukan 161 Perlembagaan Malaysia menegaskan bahawa bahasa Inggeris masih boleh dipakai sebagai bahasa rasmi negeri Sabah dan Sarawak sehingga sepuluh tahun selepas pembentukan Malaysia, atau sehingga Dewan Undangan negeri-negeri itu sendiri menetapkan. ${ }^{61}$ Peruntukan ini sekaligus menjelaskan bahawa penggunaan bahasa Inggeris terjamin sehingga 1 September 1973. Bermakna sepuluh tahun selepas Malaysia ditubuhkan pada tahun 1963, bahasa Inggeris boleh digunakan:

(a) Dalam kedua-dua Majlis Parlimen oleh anggota-anggota dari Sabah atau Sarawak.

(b) Dalam perbicaraan Mahkamah Tinggi dan Mahkamah Rendah negeri-negeri itu dan juga dalam perbicaraan Mahkamah Agung yang mendengar rayuan atau rujukan daripada Mahkamah Tinggi negeri-negeri itu dan

(c) Dalam Dewan Negara dan maksud rasmi, termasuklah maksud rasmi kerajaan Persekutuan.

Perkembangan bahasa kebangsaan di Sarawak dapat dilihat melalui isu atau ketegangan yang wujud di antara Stephan Kalong Ningkan ${ }^{62}$ dengan kerajaan pusat. Ketegangan tersebut wujud apabila Tunku Abdul Rahman, Perdana Menteri Malaysia ketika itu telah menggesa supaya Stephan Kalong Ningkan memperluaskan lagi penggunaan bahasa kebangsaan di Sarawak. Namun begitu, Ketua Menteri Sarawak tersebut telah mengambil tindakan untuk tidak melaksanakan penggunaan bahasa Melayu di Sarawak sehingga 1973. Pendirian Stephan Kalong Ningkan 
itu jelas dilihat dalam petikan ini:

We in Sarawak shall not be ready for any change until 1973-if indeed any change is required at all-and I believe the position in Sabah is substantially the same. ${ }^{63}$

Selain itu, Stephan Kalong Ningkan juga tidak melaksanakan penggunaan bahasa kebangsaan sebagai bahasa pengantar di sekolah-sekolah Sarawak. Sebaliknya beliau tetap mengekalkan penggunaan bahasa Inggeris sebagai bahasa pengantar untuk sekolah-sekolah di seluruh Sarawak. ${ }^{64}$ Tindakan Stephan Kalong Ningkan ini bukan sahaja boleh dianggap sebagai tidak menghormati dasar kerajaan persekutuan tetapi juga telah membantutkan proses perkembangan bahasa Melayu sebagai bahasa kebangsaan di Sarawak.

Selain itu, akhbar-akhbar berbahasa Melayu juga turut memainkan peranan tersendiri dalam usaha untuk memastikan perkembangan bahasa Melayu sebagai bahasa kebangsaan dan bahasa rasmi bagi negara ini di Sarawak. Antara akhbar yang terkenal ialah Utusan Sarawak. Akhbar ini aktif dalam menjalankan kegiatan untuk memperluaskan penggunaan bahasa Melayu di Sarawak sekitar tahun 1949 sehingga 1971. Akhbar yang diasaskan oleh Abang Ikhwan Zainie ini telah menjadi satu saluran penting dalam mengangkat martabat serta perkembangan bahasa kebangsaan di negeri ini. ${ }^{65}$ Jelaslah di sini bahawa perkembangan bahasa Melayu sebagai bahasa kebangsaan dan bahasa rasmi di Sabah dan Sarawak hanya dapat dinilai selepas tahun 1973. Dengan kata lain, dalam konteks bahasa kebangsaan di Sabah dan Sarawak, hanya di Sarawak sahaja yang jelas dan ada cabaran. Tetapi sebaliknya di Sabah didapati reaksinya masih tidak jelas dalam tempoh ini.

\section{Kesimpulan}

Berdasarkan perbincangan di atas dapat disimpulkan bahawa perjuangan untuk memartabatkan bahasa kebangsaan tidak hanya terbatas kepada usaha yang dilakukan dalam peringkat tempatan tetapi juga melalui usaha kerjasama kebahasaan dengan negara jiran iaitu Indonesia. Hasil kerjasama kebahasaan antara Malaysia dan Indonesia pada tahun 1959 telah memberikan manfaat terhadap kemajuan bahasa Melayu. Ini disebabkan keadaan bahasa Indonesia yang didapati lebih maju ke hadapan sesuai untuk dijadikan rujukan dan model kepada Tanah Melayu untuk memajukan lagi bahasa Melayu di negara ini.

Melalui perbincangan juga didapati usaha untuk mendaulatkan bahasa kebangsaan bukan sahaja dipikul sendirian oleh pihak kerajaan tetapi juga turut dibantu oleh individu dan pertubuhan seperti Pengetua 
Kolej Islam, PBMUM, PENA dan BBBK. Hasil usaha dan perjuangan mereka telah berjaya mendorong kerajaan supaya lebih tegas dalam usaha memajukan bahasa kebangsaan. Malahan mereka juga turut memberi sumbangan yang besar terhadap hal-hal bersabit bahasa dan kesusasteraan Melayu. Manakala dalam pilihan raya umum 1959 dan pilihan raya umum 1964 , isu bahasa menjadi manifesto wajib dalam kempen-kempen. Ahli-ahli politik bukan sahaja bijak memanipulasi isu bahasa sebagai usaha untuk meraih undian daripada pengundi tetapi juga sebenarnya telah meretakkan lagi hubungan antara kaum. Parti pembangkang dilihat cuba mencari kelemahan kerajaan dalam soal pelaksanaan bahasa kebangsaan sementara itu, orang bukan Melayu khususnya orang Cina dan orang India melalui parti-parti yang mewakili mereka cuba mengangkat kedudukan bahasa masing-masing supaya setaraf dengan bahasa Melayu. Tetapi tuntutan tersebut tidak ditunaikan oleh kerajaan yang teguh dengan pendirian menjadikan hanya bahasa Melayu dan bahasa Inggeris sebagai bahasa rasmi bagi negara ini. Seterusnya, penyertaan Sabah dan Sarawak pada tahun 1963 ke dalam Persekutuan Malaysia telah memberi rahmat kemerdekaan kepada negeri terbabit. Dalam soal bahasa kebangsaan pula, kedua-dua negeri diberikan tempoh selama sepuluh tahun (1963-1973) sebagai persediaan untuk menggunakan bahasa kebangsaan sebagai bahasa rasmi.

Oleh itu, jelaslah bahawa dalam tempoh masa 1957 hingga 1966, isu bahasa menjadi persoalan yang penting sehingga menjadi antara punca utama yang mewujudkan pergeseran antara kaum di Tanah Melayu. Oleh itu, sebagaimana yang terkandung dalam Perkara 152 Perlembagaan Persekutuan Tanah Melayu 1957 berhubung kedudukan bahasa kebangsaan selepas tempoh sepuluh tahun dari tahun tersebut, pada tahun 1967 kerajaan telah mengumumkan rang undang-undang yang dikenali sebagai Rang Undang-undang Bahasa Kebangsaan 1967. Serentak dengan pengumuman rang undang-undang tersebut perkembangan bahasa kebangsaan beranjak ke satu fasa lain.

\section{Nota}

1 Mastika, Mei 1961.

2 Soerbadi, "Malaysia dan Indonesia Ke Arah Perhubungan yang Lebih Erat Melalui Sejarah", dalam Di Sekitar Persoalan Bahasa Melayu 1957-1972, Kuala Lumpur: Dewan Bahasa dan Pustaka, 1981, hlm. 133.

3 Asraf Abdul Wahab, Awang Sariyan, Farid Onn dan Firdaus Abdullah, "Penyatuan Bahasa Melayu Se-nusantara", dalam Abdullah Hassan (penyusun), Kongres Bahasa dan Persuratan Melayu I-IV (1952-2002), Kuala Lumpur: Persatuan Penterjemah Malaysia, 2007, hlm. 366.

${ }^{4}$ Soerbadi, "Malaysia dan Indonesia", hlm. 135. 
5 Ibid., hlm. 108.

6 Asraf Abdul Wahab, Awang Sariyan, Farid Onn dan Firdaus Abdullah, "Penyatuan Bahasa Melaya", hlm. 602.

7 Ibid., hlm. 603.

8 Asmah Haji Omar, Muafakat Bahasa, Kuala Lumpur: Dewan Bahasa dan Pustaka, 2004, hlm. 3.

9 Kamaludin Muhammad (Keris Mas), Majalah Bulanan Dewan Bahasa, Kuala Lumpur: Dewan Bahasa dan Pustaka, Kementerian Pelajaran Persekutuan Tanah Melayu, Jilid III Bilangan 5 , Mei 1959, hlm. 228-232; Mastika, Mei 1961 dan Asmah Haji Omar, Muafakat Bahasa, hlm. 3.

${ }^{10}$ Ibid., hlm. 228-232.

11 Tajaan biasiswa yang diberikan oleh pemerintah Indonesia ini sebenarnya merupakan hadiah sempena kemerdekaan Tanah Melayu pada tahun 1957. Antara pelajar yang mendapat biasiswa tersebut ialah Asmah Haji Omar. Asmah Haji Omar, Muafakat Bahasa, hlm. 42.

12 Ibid., hlm. 4.

13 Ibid., hlm. 42.

${ }^{14}$ Ibid.

${ }^{15}$ Ibid., hlm. 46-50.

${ }^{16}$ Rombongan dari Persekutuan Tanah Melayu turut disertai oleh anggota-anggota lain seperti Aminuddin Baki, Zainal Abin bin Ali, Buyong bin Adil, Md. Nor bin Ahmad, Mahmud bin Ahmad, Ramli bin Abdul Hadi, Pendeta Za'ba (sebagai penasihat) dan Suffian Sahuri (sebagai setiausaha). Jawatankuasa ini dinamakan Jawatan-Kuasa Ejaan Rumi Baharu Persekutuan Tanah Melayu. Asmah Haji Omar, Muafakat Bahasa, hlm. 47.

17 Anggota-anggota lain daripada pihak Indonesia terdiri daripada E. Katoppo (anggota merangkap wakil ketua), Nur Sutan Iskandar, A.K. Hadi (setiausaha) dan Imrad Idris (diberi tugas untuk mengepalai Sekretariat Panatia Pelaksanaan Bahasa Melayu-Bahasa Indonesia. Asmah Haji Omar, Muafakat Bahasa, hlm. 4748.

18 Ibid.

${ }^{19}$ Ibid., hlm. 4.

21. Ahmat Adam, Isu Bahasa dan Pembentukan Bangsa, Kuala Lumpur: Dewan Bahasa dan Pustaka, 1994, hlm. 84.

${ }_{21}$ Mastika, Mei 1961.

${ }^{22}$ Presiden Indonesia, Sukarno telah melancarkan konfrontasi dengan slogan "Ganyang Malaysia" sebagai tanda protes terhadap penubuhan Malaysia. Sila rujuk Official Report Malaysia/Indonesia Relations: $31^{\text {th }}$ August 1957 to $15^{\text {th }}$ September 1963, Kuala Lumpur: Jabatan Chetak Kerajaan, 1963, hlm. 327; Tunku Abdul Rahman Putra, Political Awakening, Petaling Jaya: Pelanduk Publication, 1986, hlm. 77; Syed Othman Syed Omar, Rejimen Askar Melayu Diraja 1933-1968, Kuala Lumpur: Penerbit Universiti Malaya, 2005, hlm. 199.

${ }^{23}$ Soerbadi, "Malaysia dan Indonesia Kearah Perhubungan Yang Erat Melalui Sejarah", dalam Di Sekitar Persoalan Bahasa Melayu 1957-1972, hlm. 138-139.

${ }_{24}$ K.J., Ratnam., Paham Perkauman dan Proses Politik di Malaya, (diterjemahkan oleh Kassim Ahmad), Kuala Lumpur: Universiti Malaya, 1965, Bab 4. 
25 Abdul Talib Bin Hamid, Kolej Islam Malaya: Analisis Sejarah Penubuhan Dan Pentadbiran Awal, 1955-1965, Tesis Sarjana Pendidikan, Fakulti Pendidikan Universiti Malaya, Kuala Lumpur, 2001, hlm. 239.

${ }^{26}$ Surat bertarikh 7 Feb 1957, No.Ruj. Bil (3) dlm. Cim, 99/56, yang ditandatangan oleh Ustaz Zulkifli Muhammad, Setiausaha Kolej Islam Malaya, dalam S.P. 19/ 7, Arkib Negara Malaysia, hlm. 239.

27 Abdul Talib Bin Hamid, Kolej Islam Malaya, hlm. 281.

${ }^{28}$ PBMUM merupakan pertubuhan mahasiswa yang telah wujud sejak sebelum merdeka lagi. Pertubuhan ini aktif dalam memperjuangkan kedudukan bahasa Melayu. Ia juga merupakan sebuah pertubuhan pelajar yang telah melakar sejarah kerana buat pertama kalinya mengadakan tunjuk perasaan dalam menuntut supaya bahasa Melayu dijadikan bahasa pengantar di Maktab Perguruan Bahasa.

${ }^{29}$ Noordin bin Abdul Razak, Persekutuan Bahasa Melayu Universiti Malaya, Latihan Ilmiah, Jabatan Pengajian Melayu, Universiti Malaya, Kuala Lumpur, 1971, hlm. 52.

${ }^{30}$ Raja Mukhtaruddin Raja Mohd. Dain, Pembinaan Bahasa Melayu: Perancangan Bahasa Di Malaysia, hlm. 28.

${ }^{31}$ K. Ramanathan, Politik Dalam Pendidikan Bahasa, Petaling Jaya: Penerbit Fajar Bakti Sdn. Bhd, 1985, hlm. 100.

${ }^{32}$ Pilihan raya pada tahun 1959 merupakan pilihan raya pertama selepas Persekutuan Tanah Melayu mencapai kemerdekaan. Ia dijalankan secara berperingkat-peringkat mengikut negeri bermula pada 20 Mei 1959 diikuti oleh pilihan raya parlimen pada 19 Ogos 1959. Parti-parti yang bertanding ialah Parti Perikatan (UMNO-MCA-MIC) sementara itu parti pembangkang pula terdiri daripada Parti Malaya (PM), Front Sosialis Rakyat Malaya (Parti Buruh Malaya dan Parti Rakyat), Parti Islam Semalaya (PAS), Parti Negara (PN), Parti Kemajuan Rakyat (PKR) dan calon bebas. Di peringkat negeri, Perikatan telah memenangi 204 daripada 208 kerusi yang dipertandingkan dan memenangi 74 daripada 104 kerusi yang dipertandingkan di peringkat Parlimen. Sila lihat Gordon P. Means, Malaysian Politic: The Second Generation, Singapore: Oxford Universiti Press, 1991, hlm. 6; Roziah Abdul Latif, Liputan Berita Pilihanraya Tahun 1959 dan 1964 Dalam Berita Harian Dan Utusan Melayu: Satu Analisis Kandungan, Latihan Ilmiah, Jabatan Komunikasi Fakulti Sains Kemasyarakatan dan Kemanusiaan, Universiti Kebangsaan Malaysia, Bangi, Sesi 1992/1993, hlm. 16-18.

33 Proses pilihan raya 1964 dijalankan serentak di Tanah Melayu bagi pilihan raya negeri dan parlimen. Parti-parti yang bertanding dalam pilihan raya 1964 ialah Perikatan (UMNO-MCA-MIC) sementara itu pembangkang pula terdiri daripada PAS, Barisan Sosialis, PKR, Parti Tindakan Rakyat (PETIR), Parti Negara (PN) dan Parti Demokratik Bersatu (PDB). Di peringkat negeri Perikatan memenangi 240 kerusi daripada 282 kerusi yang dipertandingkan. Di peringkat parlimen pula Perikatan memenangi 89 daripada 104 kerusi yang dipertandingkan. Gordon P. Means, Malaysian Politic, hlm. 6; K. Ramanathan, Politik Dalam Pendidikan Bahasa, hlm. 91 dan Roziah Abdul Latif, 'Liputan Berita Pilihanraya', hlm. 18-19.

${ }^{34}$ Majalah Guru, Jilid 35, 31 Januari 1959, hlm. 2.

35 Ahmat Adam, "Isu Bahasa dan Pembentukkan Bangsa", dalam Asraf, Manifesto Budaya, Pupus Bahasa Pupuslah Bangsa, Kuala Lumpur: Persatuan Linguistik Malaysia, 1996, hlm. 125. 
${ }^{36}$ Utusan Melayu, 10 November 1966.

${ }^{37}$ Hussain Mohemed, Membangun Demokrasi: Pilihanraya di Malaysia, Kuala Lumpur: Karya Bistari Sdn. Bhd, 1987, hlm. 140.

"Manifesto Pilihanraya Dewan Rakyat 1959, Apakah Yang Perikatan Tawarkan Kepada Tuan, Versi Melayu-Jawi, SP 33/A/1/33, 31.12.1959, Arkib Negara Malaysia, hlm. 9.

${ }^{39}$ Ibid., hlm. 10.

40 K. Ramanathan, Politik dan Kerajaan di Malaysia, hlm. 73-84 dan Mohammed Yusoff bin Mohd Nor, 'Parti Perikatan dan Pilihan raya 1955,1959', Latihan Ilmiah, Jabatan Sejarah, Universiti Malaya, Kuala Lumpur, Sesi 1986/1987, hlm. 74-75.

${ }^{41}$ Majalah Guru, Jilid 35, 31 Januari 1959, hlm. 2.

42 R.K.Vasil, Politics In a Plural Society, Singapore: Oxford University Press, 1971, hlm. 129 dan 236.

43 Idris Johari, 'Pilihan raya Persekutuan 1959', Latihan Ilmiah, Jabatan Sejarah, Universiti Malaya, Kuala Lumpur, Sesi 1986/1987, hlm. 39.

${ }^{44}$ Ahmad Bin Md.Saman, 'Persatuan Guru-guru Melayu Kedah (PGMK), Pergerakan dan Perjuangannya, 1946-1958,' Latihan Ilmiah, Jabatan Sejarah, Universiti Malaya, Kuala Lumpur, 1978, hlm. 346.

45 Straits Times, 10 Ogos 1959

th Ahmat Adam, Isu Bahasa, hlm. 79.

${ }^{47}$ Idris Johari, 'Pilihan raya Persekutuan 1959', hlm. 40.

${ }^{18}$ Utusan Zaman, 22 November 1959.

${ }^{49}$ Utusan Melayu, 18 November 1959.

${ }^{50}$ K.J. Ratnam dan R.S. Milne, The Malayan Parliamentary Election of 1964, Kuala Lumpur: University of Malaya Press, 1967, hlm. 110; Diane K. Mauzy, Barisan Nasional: Coalition Government in Malaysia, Kuala Lumpur: Marican \& Sons (Malaysia) Sdn., Bhd, 1983, hlm. 30 dan K. Ramanathan, Politik Dalam Pendidikan Bahasa, hlm. 91

${ }^{51}$ R.S. Milne dan Diane K. Mauzy, Politik dan Kerajaan di Malaysia, Kuala Lumpur: Dewan Bahasa Dan Pustaka, 1992, hlm. 183.

52 Straits Times, 18 Julai 1964.

${ }_{53}$ R.S. Milne dan Diane K. Mauzy, Politik dan Kerajaan di Malaysia, hlm. 183-184.

${ }^{5+}$ Konsep Malaysian Malaysia ditimbulkan oleh Lee Kuan Yew untuk mewujudkan ketegangan kaum. Konsep ini juga telah mencabar kedudukan istimewa orang Melayu, kaum bumiputera di Borneo dan mencabar pemimpin-pemimpin Perikatan. Zainuddin Maidin, The Unsung Heroes, Kuala Lumpur: Utusan Publication \& Distributors Sdn. Bhd., 2004, hlm. 81 dan K. Ramanathan, Politik Dalam Pendidikan Bahasa, hlm. 91.

55 Tengku Razaleigh Hamzah, "Pemikiran Dan Visi Tun Abdul Razak Dalam Pembinaan Negara-Bangsa Malaysia Merentas Sempadan Etnik", Ceramah Agung Tahunan Anjuran Persekutuan Badan Pendidikan dan Pembangunan Melayu, Akademi Pengajian Islam Universiti Malaya, Kuala Lumpur, 30 Mac 2007, hlm. 8 . 
${ }^{56}$ Cadangan untuk menubuhkan Malaysia telah diumumkan oleh Tunku Abdul Rahman pada 27 Mei 1961 dalam majlis jamuan yang dianjurkan oleh Foreign Correspondents Association of South-East Asia di Hotel Adelphi, Singapura. Penubuhan Malaysia mengambil masa kira-kira 28 bulan bermula Mei 1961 hingga September 1963. Pada 16 September 1963, Malaysia telah dibentuk melalui gabungan yang terdiri daripada 11 buah negeri di Tanah Melayu, Dua buah negeri di Borneo iaitu Sabah dan Sarawak serta Singapura. Pembentukan Malaysia ini dicadangkan oleh Tunku Abdul Rahman adalah berasaskan untuk tujuan menjaga keselamatan dan mengekang penularan fahaman Komunis, sebagai cara mendapatkan kemerdekaan yang segera kepada Singapura, Sabah dan Sarawak, Brunei, perkongsian faedah ekonomi, membela masyarakat bumiputera di Sabah dan Sarawak, menjaga hak dan kepentingan kaum bumiputera. Sila rujuk Mohamed Noordin Sopiee, From Malayan Union to Singapore Separation: Political Unification in the Malaysia Region 1945-1965, (2nd Edition), Kuala Lumpur: University Malaya Press, 2005, hlm. 129; Nik Anuar Nik Mahmud, Konfrontasi Malaysia-Indonesia, Bangi: Penerbit Universiti Kebangsaan Malaysia, 2000, hlm. 20 dan R.S. Milne dan Diane K. Mauzy, Politik dan Kerajaan di Malaysia, hIm. 63-72.

${ }^{57}$ Mohamed Suffian bin Hashim, Mengenal Perlembagaan Malaysia, hlm. 448.

58 Asmah Haji Omar, Muafakat Bahasa, hlm. 28.

59 Ibid., hlm. 449.

${ }^{60}$ R. S. Milne dan Diane K. Mauzy, Politik dan Kerajaan di Malaysia, hlm. 73.

${ }^{61}$ Zaini Oje @ Ozea, "Perkembangan Bahasa Melayu Di Sarawak," dalam Hamzah Hamdani dan Asmah Haji Osman (Penyelenggara), Perkembangan Bahasa Melayu Di Sarawak, Jawatankuasa Penyelenggara Seminar Perkembangan Bahasa Melayu Di Sarawak (2002), 2003, Kuching: Pencetakan Nasional Malaysia Berhad, hlm. 136.

${ }^{62}$ Stephan Kalong Ningkan merupakan Ketua Menteri Sarawak yang pertama sejak pembentukan Malaysia. Beliau berkhidmat sejak 1963 sehingga 1966. Dilahirkan di Betong pada tahun 1920 dan mendapat pendidikan awal di sekolah St. Augustine. Kemudiannya beliau menjadi pegawai polis di Kapit dan meletakkan jawatan pada 1950. Antara tahun 1950-1960, beliau berkhidmat sebagai Penolong Hospital di Syarikat Minyak Shell. Pada tahun 1958, Stephan dilantik sebagai Presiden Persatuan Dayak. Kemudian beliau memegang jawatan sebagai Setiausaha Agong Sarawak National Party (SNAP) seterusnya menjadi Pengerusi SNAP. Beliau bersara dari politik pada akhir tahun 1970-an. Suffian Mansor Sejarah Pembentukan Parti Pesaka Bumiputera Bersatu Sarawak, 1959-1974, Latihan Ilmiah, Jabatan Sejarah, Fakulti Sastera dan Sains Sosial Universiti Malaya, Kuala Lumpur, Sesi 1994/1995, hlm. 33.

63 Straits Times, 3 Mei 1966.

${ }^{64}$ Suffian Mansor "Sejarah Pembentukan", hlm. 71-72.

65 Zaini Oje @ Ozea, "Perkembangan Bahasa Melayu", hlm. 135. 
